\title{
An Interactive Tool for the Human Anatomy Laboratory
}

\author{
Una Herramienta Interactiva para el Laboratorio de Anatomía Humana \\ Victor E. Maldonado-Zimbrón; Rodrigo E. Elizondo-Omaña; Beatriz A. De la Garza Cepeda; \\ Félix Vilchez-Cavazoz; Oscar de la Garza Castro \& Santos Guzmán-López
}

MALDONADO-ZIMBRÓN, V. E.; ELIZONDO-OMAÑA, R. E.; CEPEDA, G. B. A., VILCHEZ-CAVAZOZ, F.; CASTRO, G. O. GUZMÁN-LÓPEZ, S. An interactive tool for the human anatomy laboratory. Int. J. Morphol., 24(3):377-382, 2006.

SUMMARY: A multimedia program has been developed at the Departament of Human Anatomy, Medicine School of Universidad Autónoma de Nuevo León. It offers an alternative to support the traditional laboratory practice and resolve, during the dissection, the most common problems that we have already identify in our students. Some features of this program are: photography's, diagrams, information about the structures, clinical correlation and tests. All this tools were integrated in a software using Macromedia Flash. The final result is a multimedia program that will be used by students during their laboratory practice. At present, we are making a study to determine the effect that is produced in the development of the students in the anatomy lab.

KEY WORDS: Laboratory practice; Multimedia program, Dissection; Teaching anatomy.

\section{INTRODUCTION}

We live in a era when computers have become an essential part of our lives. Day by day, we use these tools to communicate in real time with distant places; we trust them to control the information of the financial market and even to control the multiple variables that occur during landings and takeoffs. Generally, they allow us to do in hours the tasks that otherwise would take days.

Sciences are not beyond this revolution. Almost all of the discoveries of the last times have been, to a certain extent, because of the computers. Some examples are the sequence of the human genome, the description of the electrons' behavior, and the advances of quantum physics. Researchers in every field have taken advantage of the power of these tools. Scientists in different continents can work in the same project; they can share and analyze results without traveling. They can even control experiments or make distance simulations. Their impact is noticeable in the frequency with which we discover new concepts or explain the already existing.

The medical sciences have characterized for being at the forefront of the innovation in the use and application of the techniques of computer science in investigation and teaching. (Rojas et al., 1999; Jastrow \& Hollinderbraumer, 2004). Molecular biology, genetics, the images of diagnosis, and the handling of clinical histories are clear examples of the use that can be given to these tools (McLane, 2005). The simulation of clinical cases and even whole cells has allowed us to access a vast array of new knowledge, useful in diagnosing and treating patients; they have also allowed us to achieve a higher knowledge of the physiological processes of our organisms (Jacobs et al., 2003a; Caudell et al., 2003). The processing and obtaining of sharper images have also provided diagnostic tools which precision was unimaginable half a century ago (Jacobs et al., 2003b; Shaffer, 2004).

Anatomy, a basic science of medicine, has taken advantage of these inventions and has applied them in teaching and visualization of the disposition of complex structures (Trelease, 2002; Silva-Lopes \& Monteiro-Leal, 2003; Inzunza \& Bravo, 2002). Despite the advantages of the use of these tools, the traditional anatomic teaching is based on the dissection of cadavers (Jones, 1997; Mc Garvey et al., 2001; Ellis, 2001; Aziz et al,. 2002) and in the use of static images in atlas (Rosse, 1999). Nowadays, different studies have tried to prove which the most effective method 
is, some authors are in favor of the traditional method (Ellis; Babinski et al., 2003; Granger, 2004; Pawlina, 2004), some others are in favor of the use of computers (McLachlan et al., 2004), and some others believe in the integration of both methods (Inzunza et al., 2003; Sinav \& Ambron, 2004; Elizondo-Omaña et al., 2005). The projects like the visible human body (Jastrow \& Vollrath, 2003) and the interactive anatomic atlas with clinical images are some examples of the utility of these new techniques (Guiraldes et al., 2001). These applications allow the students to appreciate in more detail and in a realistic way the structures and the study areas (Paalman, 2000; Inzunza \& Bravo; Sinav \& Ambron). The dynamism and interactivity of these programs are characteristics that allow the user to determine his own study pace (Drake, 1998).

In our particular experience from the Human Anatomy Department of the Medicine School of the UANL, we have identified some problems that arise in the lab practice and that can be solved with the use of the computer. The current lab program for medicine students implies them to realize at least 12 dissections trough the semester with a instructor's help, these dissections are presented to the teacher in a weekly session. Before the dissection practice, the instructor must make sure that the students have enough anatomic knowledge to make the dissection. Despite this, in practice we have realized that there are factors that prevent the students from making the most of the dissection, some of these factors are: the anatomic variations, the lack of experience in the tools handling, and above all, the confusion that results from the lack of supporting didactic material in the lab.

Because of these issues, we decided it was necessary to develop a tool to override these common problems students have during dissections. The chosen alternative was the creation of a supporting multimedia program that optimizes the use of corpse dissection. This alternative offers the advantage of integrating a great variety of resources in one program. Nowadays, there are tools created for this purpose (Inzunza \& Bravo; Inzunza et al.; Todd, 2005) although with a different approach. Our objective was to create a multimedia program, complementary to the dissection course, that solved the doubts that are frequently presented during the lab practice.

The characteristics that are needed to solve this problem are: easy handling, high resolution photographs with complementary diagrams that identify the structures, relevant information of every structure, useful clinical information, and feedback for the student through identification theoretical and about images exams. Then it was necessary to develop such software, starting from scratch without having any sort of reference we could base our project upon. The software employed to make the program was Flash MX 2004 of Macromedia, due to the facility of the integration of images with information and the high interactivity degree that can be achieved with an intuitive interphase.

The supporting multimedia program was adapted to the dissection manual that is used during the course (Hernández Ramírez et al., 1990). Six modules with 5 stuffing regions each were included, except for the first introductory block, which only includes general information about tools and suture techniques (Fig. 1). Every module has common characteristics such as: photographic images and diagrams of the study regions, information about the structures that must be identified, radiographic images, clinical correlations, and a selfevaluation.

Photographic images. The photographic images employed for the development of the program were created $e x$ professo for this purpose. The dissections were made by instructors and professors of the department, and for the photographic documentation, a Nikon reflex camera (model AF F-401s) was used. Later, the photographs negatives were digitalized by an hp scanjet 8200 series scanner (Hewlett-Packard) with a $300 \mathrm{dpi}$ resolution. The printed photographs were used to create a collection that can be used later. In total, we selected 30 dissections that show the main structures that should be identified by the students.

Images diagrams. After the digitalization of the images, they were processed in Adobe Photoshop CS to create on the image a diagram that corresponds exactly to the original photograph. This diagrams are black and white renderings of the original pictures with the structures painted with different colors. Both the photographs and the diagrams are shown at the same time, this way the student has a clear guide to understand the un-edited photograph. We think that this is one of the most important characteristics because it makes possible the identification of the structures on the corpse and not only in a drawing.

Furthermore, we included drawings to clarify in cases where the diagrams themselves were not clear enough. The drawings were kindly done by Miss Beatriz Alejandra de la Garza Cepeda, a scholarship recipient of the Departament.

Information of the identified structures. Every one of the structures that must be identified by the students are pointed in the diagrams and there is also a description of the typical anatomy that allows the student to remember 
The main menu screen (Fig. 2) shows a drawing of the human body in anatomical position, where it is possible to choose a dissection area or general information of the $\mathrm{CD}$ and the introductory block.

The secondary menu screen (Fig. 3) presents a list of the regions that can be studied in the chosen area. By passing the cursor on the name of the region, a representative image is displayed. This list also shows the options for clinical correlations and self-evaluations.

The study screen (Fig. 4) is divided into three parts that show the photographic image, the corresponding diagram, and the description that depends on the pointed structure. The photographic image and the diagram can be displaced in a synchronic way, so there can always be seen the same portion of the images. It is also possible to increase or decrease their size in order to observe the structures in more detail. By passing the mouse for every structure on the photograph, a color change (red: arteries, blue: veins, yellow: nerves, etc.) is produced in the diagram and the description appears. It is important to point that the photograph and the diagram will remain synchronized no matter if they are dragged or zoomed; therefore the diagram always corresponds with the photograph and vice versa

From any screen, it is always possible to go back to the main menu and also to exit the program.
Module of introduction. The introductory block differs from the others because it does not present images of dissections. On the other hand, this one presents information about the lab material and the adequate suture techniques. This block includes images that allow the student the visual identification of the material and a video in which the technique of the manual knot is taught step by step.

Conclusion. On the one hand, this supporting multimedia program for the lab accomplishes all of the objectives that were suggested at the beginning of the project. On the other hand, we know that there are tools that were not used in this program: 3D images, MRI, TAC, which could be useful for the students and we consider their absence as a limit.

We believe we have achieved an important first step in the integration of the computer and the traditional dissection. We trust in the advantages offered by the computer tools, such as the access to a huge variety of images and information in a simple way, to benefit our students; and also, we believe in the traditional laboratory practice as a way to learn anatomy. The most important: we think the integration of both resources could improve the achievement of students.

At present, we are making a study to determine the effect that is produced in the development of the students in the anatomy lab. We hope that our project placates the development of a higher quantity of applications that integrate the use of the computer to the lab practice as a tool that solves problems and not as a substitute of the traditional techniques.
Fig. 2. Show the main menu screen of the program. You can choose an area to study.

\section{Selecciona una Región}




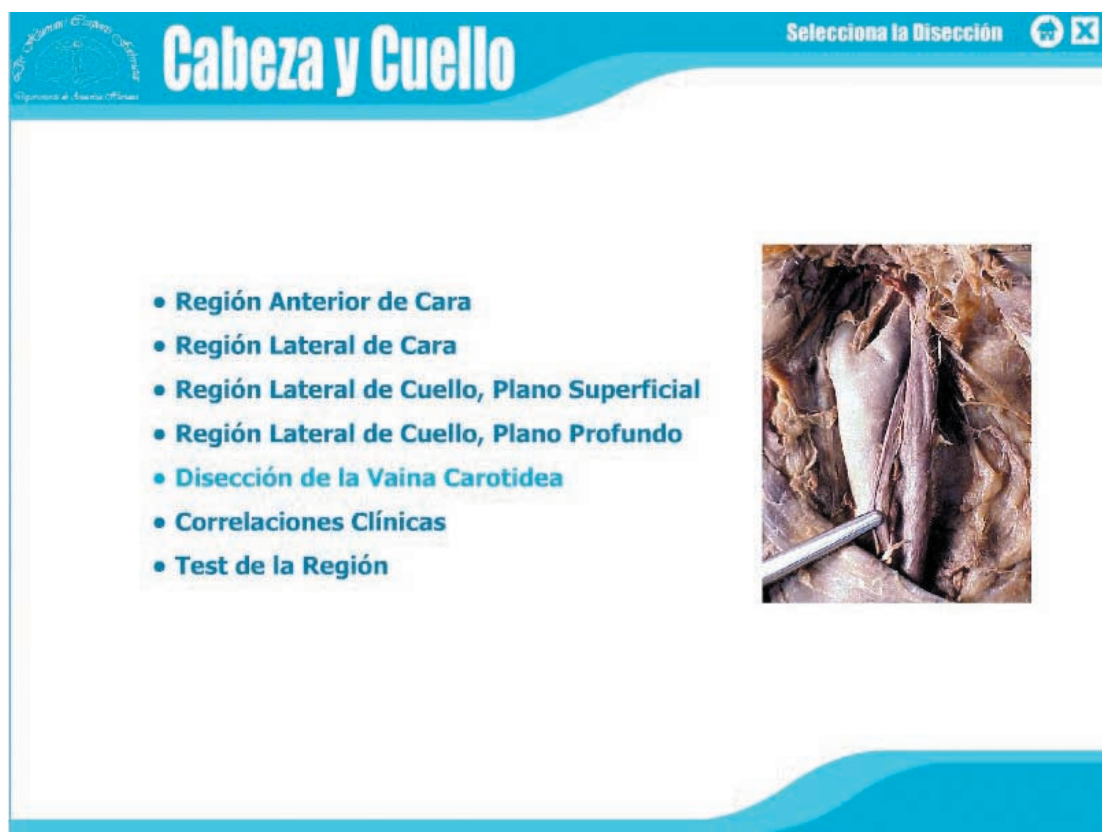

Fig. 3. Show the secondary menu screen. It is possible to select a specific region.

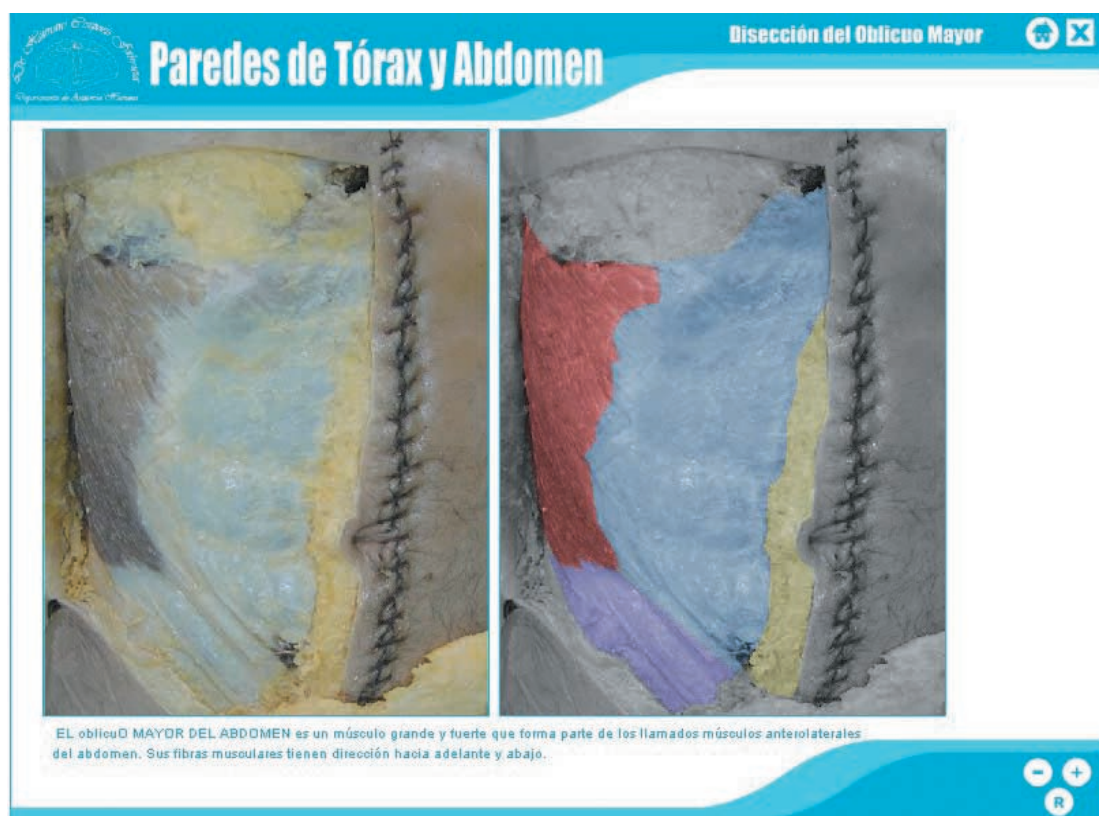

Fig. 4. Show the study screen. By passing the mouse on each structure on the photograph a short description related will appear just under the images.

MALDONADO-ZIMBRóN, V. E.; ELIZONDO-OMAÑA, R. E.; CEPEDA, G. B. A., VILCHEZ-CAVAZOZ, F.; CASTRO, G. O. GUZMÁN-LÓPEZ, S. Una herramienta interactiva para el laboratorio de Anatomía. Int. J. Morphol., 24(3):377-382, 2006.

RESUMEN: Hasta hoy, diferentes estudios han tratado de determinar la manera más efectiva de aprender Anatomía: algunos autores apoyan el método tradicional, otros prefieren el uso de computadores y algunos creen en la integración de ambos. En nuestra Escuela de Medicina utilizamos el método tradicional y el uso de computadores, así hemos desarrollado un programa multimedia que tiene por objetivo optimizar la disección como herramienta de aprendizaje. Este programa multimedia de apoyo está adaptado al manual de disecciones que es utilizado durante el curso. El programa cuenta con 6 módulos, de 5 regiones cada uno, en los que se incluyen: imágenes fotográficas y diagramas de las regiones, información acerca de las estructuras que deben ser identificadas, radiografías, correlaciones clínicas y autoevaluaciones.

PALABRAS ClAVE: Práctica de Laboratorio; Programa de multimedia; Disección, Enseñanza de la Anatomía. 


\section{REFERENCES}

Aziz, M. A.; McKenzie, J. C.; Wilson, J. S. et al. The human cadaver in the age of biomedical informatics. Anat Rec., 269:20-32, 269, 2002 .

Babinski, M. A.; Sgrott, E. A.; Luz, H. P.; Brasil, F. B.; Chagas, M. A.; \& Abidu-Figueiredo, M. La relación de los estudiantes con el cadáver en el estudio práctico de anatomía: la reacción e influencia en el aprendizaje. Int. J. Morphol., 21(2):137-42, 2003.

Caudell, T. P.; Summers, K. L.; Holten, J. et al. Virtual patient simulator for distributed collaborative medical education. Anat Rec., 270B:239, 2003.

Drake, R. L. Anatomy education in a changing medical curriculum. Anat Rec., 253B:28-31, 1998.

Drake, R. L. Gray's Anatomy for students. Churchill Livingstone, 2005.

Elizondo-Omaña, R. E.; Guzmán-López, S. \& García- Rodríguez, M. A. Dissection as a teaching tool: past, present and future. Anat. Rec., 285B:11-15, 2005

Ellis, H. Teaching in the dissecting room. Clin. Anat., 14:149-51, 2001.

Granger, N. A. Dissection laboratory is vital to medical gross anatomy education. Anat Rec., 281B:6-8, 2004.

Guiraldes, H.; Oddo, H.; Mena, B.; Velasco, N. \& Paulos, J. Enseñanza de la anatomía humana: experiencias y desafíos en una escuela de medicina. Rev. Chil. Anat., 19(2):205-12, 2001.

Hernández-Ramírez, F. et al. Anatomía y Disecciones. Ed. HEBA, 1990.

Inzunza, O. \& Bravo, H. Animación computacional de fotografías: un real aporte al aprendizaje práctico de anatomía humana. Rev. Chil. Anat., 15(1):57-64, 2002.

Inzunza, O.; D'acuña, E. \& Bravo, H. Evaluación práctica de anatomía. Rendimiento de los alumnos de primer año de medicina ante distintas formas de preguntar. Int. J. Morphol., 21(2):131-6, 2003.

Jacobs, J.; Caudell, T.; Wilks, D. et al. Integration of advanced technologies to enhance problem-based learning over distance: project TOUCH. Anat Rec., 270B:16-22, $2003 a$.

Jacobs, R. E.; Papan, C.; Ruffins, S.; et al. MRI: volumetric imaging for vital imaging and atlas construction. Nature Reviews Molecular Cell Biology 4, SS10-SS16, 2003b;

Jastrow, H. \& Vollrath, L. Teaching and learning gross anatomy using modern electronic media based on the visible human project. Clin. Anat., 16:44-54, 2003.

Jastrow, H. \& Hollinderbraumer, A. On the use and value of new media and how medical students assess their effectiveness in learning anatomy. Anat Rec., 280B:20-9, 2004.
Jones, D. G. Reassessing the importance of dissection: a critique and elaboration. Clin. Anat., 10:123-7, 1997.

Lockhart, R. D. Anatomía Humana. Interamericana, 1965.

Mc Garvey. M. A.; Farrel, T.; Conroy, R. M. et al. Dissection: a positive experience. Clin. Anat., 14:227-30, 2001.

McLachlan, J. C.; Bligh, J.; Bradley, P. \& Searle, J. Teaching anatomy without cadavers. Med. Edu., 38:418-24, 2004.

McLane S.. Designing an EMR planning process based on staff attitudes toward and opinions about computers in healthcare. CNI: computers, informatics and nursing, 23(2):85-92, 2005.

Moore, K. L. Anatomía con orientación clínica. Panamericana, 2003.

Paalman, M. H. New frontiers in anatomy education. Anat. Rec., $261 B: 47,2000$.

Pawlina, W. \& Lachman, N. Dissection in learning and teaching gross anatomy: rebuttal to McLachlan. Anat. Rec., 281B:9-11, 2004.

Rojas, M.; Montiel, E.; Montiel, J.; Ondarza, A. \& Rodríguez, H. Estudio comparativo entre metodos de enseñanza tradicional y computacional en histología humana. Rev. Chil. Anat., 17(1):81-5, 1999.

Rosse, C. Anatomy atlases. Clin. Anat., 12:293-9, 1999.

Shaffer, K. Teaching anatomy in the digital world. N. Engl. J. Med., 35:13, 2004.

Silva-Lopes, V. W. \& Monteiro-Leal, L. H. Creating a histologyembriology free digital image database using high-end microscopy and computers techniques for on-line biomedical education. Anat. Rec., 273B:126-31, 2003.

Sinav, A. \& Ambron, R. Interactive Web-based programs to teach functional anatomy:the pterygopalatine fossa. Anat Rec., 279B:48, 2004.

Todd, G. L. Interactive dissecting guide. FASEB J. 2005; Abstract 1359:775.7.

Trelease, R. B. Anatomical informatics: millennial perspectives on a newer frontier. Anat. Rec., 269:224-35, 2002.

Van de Graaff, K. Human Anatomy. 5. ed. McGraw Hill, 2000.

Correspondence to:

Dr. Rodrigo E. Elizondo-Omaña

Departament of Human Anatomy,

Medicine School, Universidad Autónoma de №vo León.

Ave. Madero y Dr. Aguirre Pequeño s/n. Col.

Mitras centro, Monterrey, N.L.

C.P. 64460

MÉXICO

Email:rod_omana@yahoo.com

Received : 23-03-2006

Accepted: 25 -06-2006 